\title{
PENGARUH PERSEPSI DAMPAK MEROKOK DAN FEAR APPEAL TERHADAP MOTIVASI BERHENTI MEROKOK SERTA IMPLIKASINYA PADA PERILAKU MEROKOK MAHASISWA DI KOTA PEKANBARU
}

\author{
Julina \\ Fakultas Ekonomi dan Sosial UIN Sultan Syarif KAsi Riau - Pekanbaru \\ E-mail: julina@uin-suska.ac.id
}

\begin{abstract}
Abstrak
Rokok merupakan produk yang secara terang-terangan menyatakan berbahaya bagi para konsumen. Namun, produk ini tetap saja banyak diminati meskipun dapat memberikan efek yang buruk. Berdasarkan fenomena tersebut penelitian ini bertujuan untuk mengetahui pengaruh fear appeal dan persepsi dampak merokok terhadap motivasi berhenti merokok. Selanjutnya juga diteliti apakan motivasi berhenti merokok akan berpengaruh pada perilaku merokok. Data dikumpulkan menggunakan kuesioner dan selanjutnya dianalisis menggunakan deskripsi kuantitatif dan analisis regresi. Sebanyak 200 orang responden yang berasal dari dua universitas negeri berpatisipasi dalam penelitian ini. Hasil penelitian menemukan bahwa persepsi dampak merokok dan fear appeal berpengaruh signifikan secara simultan. Namun, hasil uji parsial menunjukkan bahwa pengaruh dari persepsi dampak merokok tidak signifikan. Hasil penelitian selanjutnya menemukan bahwa motivasi berhenti merokok berpengaruh negatif dan signifikan terhadap perilaku merokok. Hal ini menandakan bahwa semakin tinggi motivasi berhenti merokok mengakibatkan penurunan perilaku merokok. Hasil penelitian ini dapat menjadi rujukan bagi berbagai pihak untuk meningkatkan motivasi berhenti merokok agar perilaku merokok yang sangat membahayakan diri dan lingkungan dapat diturunkan.
\end{abstract}

Kata Kunci: Fear Appeal, Persepsi Dampak Merokok, Motivasi Berhenti Merokok, Perilaku Merokok

\section{PENDAHULUAN}

Di seluruh dunia, konsumsi tembakau dianggap sebagai penyebab kematian yang dapat dicegah (WHO, 2009). Namun demikian, merokok tetap menjadi trend an dampaknya terhadap kesehatan global diasumsikan meningkat dimasa mendatang. Indonesia adalah negara ketiga terbesar untuk perokok aktif di dunia. Diperkirakan terdapat 66 juta perokok aktif di Indonesia dan 3.9 jutanya adalah anak-anak yang berumur 10 sampai 14 tahun. Frekuensi merokok di Indonesia untuk Negara-negara ASEAN menempati ranking teratas. Rata-rata orang Indonesia merokok sebanyak 12.4 rokok per hari. Diperkirakan sebanyak 200.000 orang Indonesia meninggal karena sakit yang disebabkan oleh merokok. Data dari WHO menyatakan bahwa konsumsi rokok membunuh 100 juta orang di abad ke 20 (Sulistyawati, 2015). 
Terdapat perokok baru setiap hari sebanyak 36 ribu orang dan remaja perokok baru sebanyak 13 juta orang per tahun. Industri tembakau menargetkan anak muda untuk mempertahankan Industri ini. Hal ini dimungkinkan karena harga rokok di Indonesia juga sangat terjangkau dan murah (Novia, 2015).

Pemerintah telah membuat berbagai upaya untuk mencegah perilaku, kognitif, dan fenomena fisiologis, keinginan kuat untuk mengonsumsi bahan tersebut, kesulitan dalam mengendalikan penggunaannya, memberikan prioritas pada penggunaan bahan tersebut daripada kegiatan lain, meningkatnya toleransi dan dapat menyebabkan keadaan gejala putus zat. Selanjutnya, Peraturan Menteri Kesehatan Republik Indonesia nomor 28 tahun 2013 mendiskusikan tambahan peringatan kesehatan dan informasi kesehatan pada kemasan produk tembakau. Kebijakan tersebut efektif pada tanggal 24 Juni 2014. Label ini bertujuan untuk meningkatkan persepsi risiko terkait perilaku merokok dan menimbulkan perasaan takut agar dapat memotivasi perokok untuk berhenti merokok.

Meskipun langkah ini belum dapat mengurangi jumlah perokok saat ini, usaha dan kesadaran bahaya merokok masih dilakukan, dan harus diperkenalkan dari sejak kecil. Hal ini disebabkan oleh banyak perokok aktif adalah generasi muda. Tujuan penelitian ini adalah untuk menemukan pengaruh persepsi dampak merokok dan fear appeal terhadap motivasi untuk berhenti merokok dan dampak selanjutnya terhadap perilaku merokok mahasiswa di Pekanbaru. Motivasi perilaku merokok. Diantaranya melalui Penerbitan beberapa peraturan. Peraturan Pemerintah Indonesia No. 109 Tahun 2012 tentang pengamanan bahan yang mengandung zat adiktif berupa produk tembakau bagi kesehatan. Zat adiktif adalah yang menyebabkan adiksi atau ketergantungan yang membahayakan kesehatan dengan ditandai perubahan adalah kekuatan utama bagi seseorang untuk memenuhi kebutuhannya. Motivasi yang tinggi akan memiliki dampak terhadap perilaku yang lebih besar. Disisi lain, terdapat beberapa faktor yang dapat mempengaruhi motivasi. Dalam penelitian ini, pengaruh persepsi dampak merokok dan fear appeal akan diuji untuk memprediksi motivasi untuk berhenti merokok. Rokok memiliki dampak negatif tidak hanya untuk perokok itu sendiri, akan tetapi juga orang lain disekitarnya, yang biasa disebut perokok pasif. Seseorang yang peduli pada orang lain disekitarnya diharapkan memiliki motivasi yang besar untuk berhenti merokok. Selain itu, beberapa usaha dilakukan untuk mendorong seseorang berhenti merokok dan mencegah munculnya perokok baru dengan menggunakan fear appeal. Dengan menggambarkan dampak negatif yang disebabkan oleh rokok, diharapkan dapat mendorong orang untuk berperilaku sehat dengan berhenti merokok. Selain itu, dampak motivasi untuk berhenti merokok terhadap perilaku merokok akan di uji pula pada penelitian ini untuk menemukan apakah terhadap pengaruh yang kuat antara kedua variabel tersebut. 


\section{TINJAUAN PUSTAKA}

\section{Perilaku Merokok}

Merokok diasosiasikan dengan hasil ekspektasi positif dan negatif. Para perokok memiliki ekspektasi bahwa merokok membantu menghadapi stress dan dihubungkan dengan hasil sosial seperti merasa keren, atraktif, dan bebas ketika merokok. Mereka juga memahami bahwa merokok memiliki konsekuensi merusak kesehatan dan efek samping yang tidak menyenangkan seperti bau rokok atau merasa kotor. Namun kenyataannya, meskipun perokok memahami konsekuensi negatif tersebut, mereka mengabaikannya dan menjustifikasi perilaku mereka dengan hasil yang positif (Glock, 2012). Padahal, rokok memiliki pengaruh negatif tidak hanya untuk perokok itu sendiri, akan tetapi juga orang lain yang berada disekitar mereka. Terutama bagi wanita hamil, merokok tidak hanya berdampak pada dirinya tetapi juga pada bayi yang belum dilahirkan. Greenway et al., (2012) menguji bias kesadaran pada informasi terkait merokok pada wanita hamil dan hubungannya dengan sikap dan pengalaman merokok. Hasil penelitian mereka menemukan bahwa bias kesadaran untuk merokok meningkat pada perempuan hamil yang mempersepsikan perokok pasif membahayakan janin.

Banyak penelitian yang menguji risiko dan manfaat yang dipersepsikan terkait dengan merokok telah memfokuskan pada risiko terus merokok dan manfaat berhenti merokok The Agency for Health Care Policy and Research (Fiore et al., 2000) menyatakan bahwa para petugas kesehatan harus mengantisipasi konsekuensi negatif jika terus merokok (misalnya serangan jantung dan strok, kanker paru-paru dan lainnya.) dan menekankan pada manfaat berhenti merokok (misalnya kesehatan yang membaik, merasa diri lebih baik) untuk membantu pasien berhenti merokok. Selanjutnya, diprediksi bahwa risiko yang dipersepsikan akan berhubungan negatif dengan motivasi berhenti merokok. Temuan ini mendukung penelitian sebelumnya yang mengindikasikan bahwa risiko dan manfaat yang dipersepsikan berhubungan dengan niat berhenti (misalnya, Sutton et al., 1990) dan respon perlakuan aktual (misalnya, Gibbons et al, 1991; McKee et al. 2005).

Selama empat puluh tahun terakhir, Pemerintah Australia telah mempromosikan pesan anti merokok. Pada Tahun 1972, pesan anti merokok berbentuk produksi dan distribusi simbol-simbol yang meminta perokok untuk tidak merokok di area terbukat. Selanjutnya, pada tahun 1980an dan 1990an ketika efek yang sebenarnya dari merokok diketahui, dimulailah kampanyekampanya intervensi (Tobacco in Australia, 2013). Sejak saat itu, Pemerintah Australia bertujuan untuk meningkatkan kesadaran akan bahaya rokok, memotivasi berhenti merokok, dan menghambat adopsi merokok (Miller et al., 2011). Dengan 
lebih dari 15,000 kematian terkait dengan merokok setiap tahun di Australia, dan peningkatan biaya sosial yang dikaitkan dengan rokok (estimasi \$31.5 milyar pada Tahun 2004-2005; Cancer Council NSW, 2013), penelitian dirancang untuk memahami bagaimana cara terbaik pemerintah membuat pesan untuk berhenti merokok penting dilakukan baik bagi individu, ekonomi, dan masyarakat secara keseluruhan (Rayner et al, 2014).

Penelitian yang dilakukan oleh Chen et al., (2006) mencoba menemukan peran persepsi norma merokok dalam memediasi tiga kelompok faktor-faktor yang secara umum dianggap sebagai risiko yaitu merokok diantara orang lain yang mungkin terpengaruh, paparan terhadap media yang mendukung tembakau, dan sikap pribadi pada rokok terhadap perilaku merokok di Cina. Hasilnya menemukan bahwa merokok diantara orang lain yang mungkin terpengaruh (teman-teman baik, ayah, ibu, guru laki-laki, guru perempuan, dan orang-orang dewasa secara umum) dan kondisi psikologis positif yang dipersepsikan dan penghargaan sosial dari merokok berkorekasi dengan perilaku merokok, sementara paparan terhadap media yang mendukung tembakai tidak berkorelasi signifikan. Efek mediasinya lebih besar untuk perokok dewasa $(70 \%$ sampai 90\%) dibandingkan teman baik yang perokok $(11 \%$ sampai $16 \%$ ).

Gould et al., (2015) menggunakan Extended Parallel
Process Model (EPPM) yang diadaptasi dari Witte et al., (1996, 2001) menganalisis sikap dan perilaku perokok. Menurut teori ini jika terdapat risiko kesehatan, orang akan mengendalikan bahaya ini dengan merubah sikap dan perilaku menjadi lebih positif. Atau, akan merasa takut dan mencoba mengendalikan emosi ketakutan tersebut dengan menolak dan mengurangi nilai pesan .

\section{Persepsi Dampak Merokok}

Merokok merupakan penyebab kematian dibanding faktor-faktor risiko lainnya. Tentu saja perokok memiliki risiko dua kali lebih tinggi terkena strok dan kanker saluran pernafasan. Selain itu, juga terdapat 25 persen risiko lebih tinggi terkena kanker paruparu. Lebih jauh, berbagai penyakit juga lebih sering terjadi pada perokok dibandingkan bukan perokok (Ioakeimidis, Vlachopoulos, \& Tousoulis 2016). Di Amerika Serikat, penggunaan tembakau bertanggung jawab atas 450,000 kematian dan 170,000 kematian akibat kanker setiap tahun. Lebih dari $90 \%$ perokok dewasa mulai merokok sejak remaja (Halpern-Felsher, et.al., 2004).

Individu umumnya memperspesikan diri mereka tidak akan mendapatkan hasil negatif dibandikan dengan orang lain dan malahan kemungkinan menikmati hal positif dari merokok - suatu fenomena yang disebut sebagai optimism yang tidak realistis (unrealistic optimism), juga disebut sindrom bias optimistis (optimistic bias), ilusi positif 
(positive illusion), imunitas unik (unique invulnerability), dan itu adalah hal yang tidak akan terjadi pada saya (it can't happen to me). Serupa dengan temuan pada perokok dewasa, perokok remaja juga melaporkan probablitas nasib buruk yang lebih tinggi bagi orang lain dibandingkan terjadi pada diri sendiri. Bahkan, anak-anak yang lebih muda menilai diri mereka kurang berisiko pada dampak negatif dibandingkan temantemannya. Superioritas ilusi menggambarkan kecenderungan untuk mendefinisikan diri mereka dengan cara yang membuat kita terlihat lebih baik (lebih beruntung) dibandingkan orang lain (Henriksen dan Flora, 1999). Jika individu perokok tidak beranggapan mereka membahayakan baik dirinya sendiri maupun orang lain akan, maka hal ini akan menurunkan motivasinya untuk berhenti merokok.

\section{Fear Appeal}

Implementasi dan
keefektifvan tampilan yang
menakutkan (fear appeal)
telah
menjadi subjek perdebatan yang
hebat dalam literature perikalnan
dan perilaku konsumen selama 55
tahun (Rayner et al, 2014). Salah
satu faktor lingkungan social yang
penting yang mempengaruhi
perilaku merokok adalah paparan
terhadap media yang mendukung
tembakau. Penelitian-penelitian
pada tahun 1980an dan 1990an
mengindikasikan bahwa
periklanan tembakau dan aktivitas
promosi adalah katalisator penting
dalam perilaku merokok (Chen et
al., 2006:360). Kampanye anti

rokok baru-baru ini telah menggunakan strategi pesan yang dikaitkan dengan menciptakan persepsi realistis terhadap popularitas merokok. Misalnya, kampanye media dari Vermont Tobacco Control Program menargetkan anak-anak berumur 10 sampai 13 tahun, menggunakan pesan bahwa "8 dari 10" remaja tidak merokok. Kampanye lain telah menggunakan pesan yang kurang direktif untuk denormalisasi tembakau. Misalnya, kampanye TRUTH di Florida, kampanye Target Market di Minnesota, dan kampanye the American Legacy Foundation's (Legacy's) berusaha untuk mengubah persepsi bahwa pemberontakan dan merokok merupakan hal yang sama. Kampanye-kampanye ini menggambarkan risiko yang dihadapi para generasi muda terbebas dari pemasaran industri tembakau (Davis et al., 2007)

Maddux \& Rogers (1983) mengutip dari Higbee, (1969) dan Rogers, (1975), mendfinisikan komunikasi fear appeal sebagai suatu usaha untuk mempengaruhi atau membujuk orang melalui ancaman bahaya atau penyakit dimasa depan. Penggunaan fear appeals meliputi berbagai topik, termasuk perilaku merokok, kesehatan gigi, TBC, dan lainlain. Fear appeal mencoba merubah sikap dan perilaku orang menjadi lebih sehat. Meskipun terdapat beberapa inkonsistensi dalam temuan empiris, fear appeals ditemukan efektif umumnya pada perubahan sikap dan perilaku. Menurut formulasi 
asli dari teori motivasi perlindungan (Protection Motivation Theory) dari Rogers, (1975), komunikasi fear appeal dimulai pada proses penilaian kognitif yang terdiri dari (1) kerugian atau bahaya dari sesuatu yang mengancam,

kemungkinan terjadinya peristiwa, dan (3) keefektivan respon melakukan yang direkomendasikan. Proses-proses kognitif ini, selanjutnya memediasi efek persuasive fear appeal dengan menggunakan motivasi melindungi, suatu variabel intervening yang muncul, mempertahankan, dan aktivitas langsung untuk melindungi diri sendiri dari bahaya (Maddux dan Rogers, 1983).

Penelitian yang dilakukan oleh Glock et al., (2012) menemukan bahwa label peringatan yang berlawanan dengan hasil positif merokok dapat membuat sikap implisit perokok dan harapan hasil eksplisit terhadap merokok semakin menuru dan bahkan mengurangi perilaku merokok dalam jangka pendek. Benar bahwa label peringatan terkait kesehatan penting dalam menginformasikan kepada masyarakat tentang konsekuensi kesehatan yang diderita akibat merokok. Namun, konsekuensi kesehatan sering muncul bertahun-tahun setelah merokok. Sebaliknya, label peringatan mereka menunjukkan konsekuensi jangka pendek dari merokok. Mereka mengekspos alasan positif perokok untuk menjustifikasi perilaku mereka sendiri. Oleh karena itu, menurut mereka label peringatan yang berlawanan mungkin akan setara atau lebih bernilai dalam menargetkan perokok saat ini atau mencegah anak-anak muda untuk mulai merokok. Manfaat lain dari label peringatan yang kontradiksi adalah tidak menggunakan teknik mengancam. Argumen mereka terhadap merokok tidak hanya mengeksploitasi alasan positif merokok. Jenis periklanan yang kurang mengancam ini membuat respon bertahan dan reaksi psikologis tidak diperlukan. (Glock, et al., 2012). Fear appeal dianggap akan mampu mempengaruhi motivasi perokok untuk berhenti merokok.

\section{Motivasi untuk Berhenti} Merokok

Untuk menghentikan kebiasaan merokok, terdapat tahapan-tahapan tertentu yang harus dilalui termasuk motivasi (periode awal seorang perokok siap untuk berusaha berhenti merokok), tahap awal penghentian (periode beberapa minggu untuk berhenti merokok setelah perokok berkomitmen untuk berhenti), penghentian (periode dua minggu setelah berusaha berhenti merokok), dan pemeliharaan (dua minggu setelah periode berhenti yang memfokuskan pada pemeliharaan pantangan (Baker et al., 2011) dalam Garey (2016). Bagi kebanyakan perokok, berhenti merokok sangat sulit dilakukan, karena nikotin sangat adiktif dan penghentian terkait dengan gejala depresi. Untuk menghadapi gejala depresi dan untuk mendapatkan 
ketenangan, konseling psikososial dan farmakoterapi adalah metode yang efektif terutama apabilla kedua metode ini digunakan secara bersamaan (Ioakeimidis, et.al., 2016) . Lebih dari separuh remaja menyatakan minat untuk berhenti merokok, namun mereka jarang berhasil. Temuan ini, disertai dengan perubahan perkembangan yang terjadi dari remaja menuju dewasa muda, membutuhkan intervensi yang berorientasi pada kebutuhan unik dewasa muda. Selain itu, kebutuhan kritis untuk memfokuskan upaya intervensi pada orang dewasa muda digarisbawahi oleh data berskala besar yang menunjukkan bahwa berhenti merokok sebelum usia 30 tahun dapat mengurangi lebih dari 95\% kematian terkait tembakau (MacPherson, Collado, Ninnemann, \& Hoffman, 2016).

Teori Planned BehaviorReasoned Action menawarkan mekanisme yang masuk akal untuk menggambarkan peningkatan risiko penggunaan tembakau di kalangan remaja yang terkait dengan sikap mereka terhadap merokok. Bila seseorang percaya merokok itu bermanfaat, mereka akan cenderung memiliki niat merokok (Chen, 2006). Ada hubungan yang kuat antara persepsi stres dan merokok, kemungkinan besar karena hubungannya dengan proses afektif dan peraturan mereka. Garey et al., (2015) merangkum beberapa penelitian terdahulu dan menemukan bahwa stres yang dirasakan lebih tinggi juga terkait dengan tingkat ketergantungan nikotin yang lebih tinggi, kurang percaya diri untuk berhenti merokok, dan kemungkinan yang lebih rendah untuk berhenti merokok dan sedikit waktu untuk kambuh lagi. Selanjutnya, mereka mengatakan bahwa apakah hubungan antara persepsi stres dan merokok dijelaskan oleh penghindaran eksperimental khusus merokok tetap tidak diketahui. Penelitian sebelumnya menyatakan bahwa perbedaan individu dalam faktor penguat mood (misalnya, kekhawatiran, kepekaan kecemasan) secara tidak langsung berkaitan dengan penghalang yang lebih besar untuk penghentian, jumlah usaha berhenti sebelumnya, dan harapan merokok manajemen mood yang lebih baik melalui penghindaran eksperimental khusus merokok. Temuan ini mengundang eksplorasi empiris lebih lanjut tentang peran penghindaran pengalaman merokok spesifik pada konstruksi modulasi mood lainnya seperti tekanan yang dirasakan. Mungkin perokok dengan tingkat stres yang dirasakan lebih banyak merasakan kejadian hidup dan sensasi internal karena lebih menyulitkan pribadi. Dengan demikian, perokok ini mungkin lebih cenderung merespons kesusahan seperti itu dengan melarikan diri/ menghindari, dan oleh karena itu, menggunakan rokok sebagai sarana untuk mengurangi tekanan mereka. Perilaku ini, pada gilirannya, mungkin terkait dengan perilaku merokok yang lebih parah atau bermasalah (misalnya, tingkat ketergantungan 
yang lebih besar, hambatan yang dirasakan lebih banyak untuk berhenti merokok, dan lebih banyak masalah saat berhenti merokok). Menurut Garey et al., (2016) dampak negatif yang lebih besar terhadap pengurangan motif merokok diperkirakan kemungkinan lebih besar untuk memulai pengobatan untuk penghentian merokok. Hasil menunjukkan bahwa pengaruhi negatif mengurangi motif merokok dapat berdampak positif pada inisiasi pengobatan. Motivasi untuk berhenti merokok diduga akan mempengaruhi perilaku merokok seseorang.

\section{METODE PENELITIAN}

Penelitian ini berlokasi di Pekanbaru, ibu kota Provinsi Riau. Sebanyak 200 responden setuju untuk ikut serta dalam penelitian ini.
Mereka adalah mahasiswa pada dua universitas negeri di Pekanbaru. Data dikumpulkan dengan menggunakan kuesioner terdiri dari dua puluh enam pertanyaan. Kemudian dianalisis validitas dan reliabilitasnya dengan menggunakan korelasi Pearson dan Cronbach's Alpha. Regresi linier berganda digunakan untuk melihat dampak persepsi merokok dan fear appeal terhadap perilaku merokok. Analisis lebih lanjut menggunakan regresi sederhana untuk mengetahui pengaruh motivasi berhenti merokok terhadap perilaku merokok

\section{HASIL DAN PEMBAHASAN}

Sebelum dilakukan analisis
lebih lanjut, data yang telah
dikumpulkan sebelumnya diuji
validitas dan reliabilitasnya. Hasil
pengujian validitas dan reliabilitas
dapat dilihat pada tabel berikut.


Tabel 1

Uji Validitas dan Reliabilitas

\begin{tabular}{|c|c|c|c|}
\hline Variable & Item & $\begin{array}{c}\text { Pearson } \\
\text { Correlation }\end{array}$ & Cronbach's Alpa \\
\hline \multirow{6}{*}{$\begin{array}{l}\text { Persepsi } \\
\text { dampak } \\
\text { merokokok }\end{array}$} & PI1 & 0.674 & \multirow[t]{6}{*}{0.695} \\
\hline & $\mathrm{PI} 2$ & 0.483 & \\
\hline & PI3 & 0.695 & \\
\hline & PI4 & 0732 & \\
\hline & PI5 & 0.600 & \\
\hline & PI6 & 0.571 & \\
\hline \multirow[t]{6}{*}{ Fear Appeal } & FA1 & 0.562 & \multirow[t]{6}{*}{0.812} \\
\hline & FA2 & 0.735 & \\
\hline & FA3 & 0.818 & \\
\hline & FA4 & 0.805 & \\
\hline & FA5 & 0.582 & \\
\hline & FA6 & 0.777 & \\
\hline \multirow{8}{*}{$\begin{array}{l}\text { Motivasi } \\
\text { berhenti } \\
\text { merokok }\end{array}$} & MQ1 & 0.223 & \multirow[t]{8}{*}{0.782} \\
\hline & MQ2 & 0.703 & \\
\hline & MQ3 & 0.715 & \\
\hline & MQ4 & 0.523 & \\
\hline & MQ5 & 0.629 & \\
\hline & MQ6 & 0.669 & \\
\hline & MQ7 & 0.704 & \\
\hline & MQ8 & 0.590 & \\
\hline \multirow{6}{*}{$\begin{array}{l}\text { Perilaku } \\
\text { Merokok }\end{array}$} & SB1 & 0.651 & \multirow[t]{6}{*}{0.713} \\
\hline & SB2 & 0.635 & \\
\hline & SB3 & 0.576 & \\
\hline & SB4 & 0.675 & \\
\hline & SB5 & 0.505 & \\
\hline & SB6 & 0.497 & \\
\hline
\end{tabular}

Berdasarkan uji validitas dan reliabilitas seperti terlihat pada Tabel 1, empat item (PI2, MQ1, SB5, dan SB6) harus dikeluarkan dari analisis karena tidak sesuai dengan aturan praktis untuk uji validitas. Untuk uji reliabilitas, semua variabel memiliki Cronbach Alpha lebih dari 0,7, kecuali untuk persepsi dampak merokok. Setelah dikeluarkan satu item, nilai tertinggi Cronbach Alpha adalah 0,695 .
Tabel 2 berikut mengilustrasikan pengaruh persepsi dampak merokok dan fear appeal terhadap motivasi berhenti merokok secara parsial. Data pada Tabel 2 menunjukkan bahwa hanya fear appeal yang memiliki pengaruh yang signifikan sedangkan persepsi dampak merokok tidak signifikan. Secara simultan, mereka memiliki pengaruh signifikan dengan nilai $\mathrm{F}$ sebesar 7,639. 
Tabel 2

Pengaruh Persepsi Dampak Merokok dan Fear Appeal terhadap Motivasi Berhenti Merokok

Coefficients $^{\mathrm{a}}$

\begin{tabular}{|c|c|c|c|c|c|c|}
\hline \multirow{2}{*}{\multicolumn{2}{|c|}{ Model }} & \multicolumn{2}{|c|}{ Unstandardized Coefficients } & \multirow{2}{*}{$\begin{array}{c}\text { Standardized } \\
\text { Coefficients } \\
\text { Beta }\end{array}$} & \multirow[b]{2}{*}{$\mathrm{t}$} & \multirow[b]{2}{*}{ Sig. } \\
\hline & & $\mathrm{B}$ & Std. Error & & & \\
\hline \multirow[t]{3}{*}{1} & (Constant) & 15,538 & 2,025 & & 7,672 &, 000 \\
\hline & Fear Appeal &, 294 & ,079 & 257 & 3,710 &, 000 \\
\hline & $\begin{array}{l}\text { Persepsi dampak } \\
\text { merokok }\end{array}$ &, 078 &, 107 & 050 & ,722 & ,471 \\
\hline
\end{tabular}

Persepsi bahwa media lebih berbahaya bagi orang lain, dan tidak berbahaya bagi dirinya -efek orang ketiga- adalah temuan yang sangat kuat di komunikasi massa (Henriksen \& Flora, 1999). Barangkali hal ini pula yang membuat orang merasa aman meskipun bahaya merokok telah banyak dipaparkan. Tobacco Control Support Center (TCSC) Indonesia merilis hasil penelitian tentang keefektivan peringatan kesehatan menggunakan gambar pada kemasan rokok di Indonesia. Hasilnya adalah gambar yang paling menakutkan dan memotivasi perokok untuk berhenti adalah gambar kanker paru-paru. Gambar kanker paru-paru dianggap sebagai fear appeal yang paling efektif untuk membuat $86.1 \%$ perokok berhenti merokok dan membuat $91.5 \%$ mantan perokok tetap berhenti merokok. Terdapat tiga jenis gambar pengaruh rokok yang ditunjukkan kepada 5,409 responden secara random di 13 kabupaten dan kota, yaitu kanker mulut, perokok laki-laki dengan latar belakang tengkorak, kanker tenggorokan, perokok yang menggendong anak kecil, dan kanker paru-paru (Hafid, 2015).

Hasil penelitian oleh Rayner $e t$ al., (2014) menunjukkan bahwa pesan intensitas tinggi mempromosikan daya ingat yang superior. Mereka menyarankan bahwa sifat mengejutkan dari pesan intensitas tinggi dengan cepat ditanamkan ke dalam pikiran individu. Berdasarkan hasil tersebut, maka saat fear appeal ditampilkan dengan intensitas tinggi, maka akan tertanam dalam memori konsumen dan diharapkan dapat meningkatkan motivasi untuk berhenti merokok. Pengetahuan tentang risiko dan manfaat yang dirasakan terkait dengan penghentian merokok sangat penting untuk kampanye pendidikan publik dan dapat memberi tahu strategi intervensi yang dirancang untuk mengubah keyakinan spesifik antar gender yang terkait dengan niat perilaku yang rendah untuk berhenti merokok. (McKee et al. 2005).

Tabel 3 berikut ini menggambarkan temuan penelitian berupa pengaruh negatif yang signifikan antara motivasi untuk berhenti merokok dan perilaku merokok. Motivasi akan mendorong seseorang untuk berperilaku dengan cara tertentu yang menurut mereka akan memenuhi kebutuhan mereka. Motivasi tinggi untuk berhenti merokok akan mengurangi perilaku merokok. 
Table 3

Pengaruh Motivasi Berhenti Merokok terhadap Perilaku Merokok

\begin{tabular}{|c|c|c|c|c|c|c|}
\hline \multirow{2}{*}{\multicolumn{2}{|c|}{ Model }} & \multicolumn{2}{|c|}{ Unstandardized Coefficients } & \multirow{2}{*}{$\begin{array}{c}\text { Standardized } \\
\text { Coefficients }\end{array}$} & \multirow[b]{2}{*}{$\mathrm{t}$} & \multirow[b]{2}{*}{ Sig. } \\
\hline & & $\mathrm{B}$ & Std. Error & & & \\
\hline & (Constant) & 18,419 & 1,164 & & 15,822 &, 000 \\
\hline & $\begin{array}{l}\text { Motivasi berhenti } \\
\text { merokok }\end{array}$ &,- 132 &, 052 &,- 178 & $-2,549$ &, 012 \\
\hline
\end{tabular}

a. Dependent Variable: Perilaku Merokok

Halpern-Felsher, et.al., (2004) memeriksa manfaat dan risiko sosial dan risiko fisik terkait merokok antara remaja yang telah merokok vs belum merokok dan berniat vs tidak berniat merokok. Mereka menemukan bahwa perokok remaja dan mereka yang berniat merokok memperkirakan kesempatan mereka untuk mengalami hasil negatif terkait rokok sama kecilnya dengan bukan perokok dan yang tak berniat merokok.. Perokok dan yang berniat merokok juga melaporkan kemungkinan kecanduan lebih sedikit dibandingkan orang lain. Sebaliknya, perokok remaja dan remaja yang berniat merokok mempersepsikan kesempatan untuk mengalami manfaat terkait merokok lebih banyak daripada bukan perokok dan yang tidak berniat merokok. Lebih jauh lagi, mereka menyarankan bahwa daripada hanya berfokus pada risiko kesehatan sebagai cara untuk mencegah perokok remaja, peran risiko dan manfaat sosial yang dirasakan pada perokok remaja dapat menjadi fokus penting tambahan untuk intervensi. Selain itu, upaya harus dilakukan untuk meningkatkan kesadaran remaja terhadap sifat adiktif rokok.

\section{PENUTUP}

Dampak berbahaya dari merokok telah banyak diketahui. Namun, banyak orang tetap merokok. Di berbagai belahan dunia, terdapat usaha-usaha untuk meningkatkan kesadaran masyarakat tentang dampak negatif dari merokok. Bagi para perokok, mereka mendapatkan manfaat yang mereka persepsikan - meskipun mereka mengetahui risikonya - hal ini tertutupi oleh persepsi mereka atas manfaat yang diperoleh. Di Indonesia, baru beberapa saat ada upaya dari pemerintah untuk menampilkan gambar-gambar yang mengerikan akibat merokok. Penelitian ini menemukan bahwa untuk sampel mahasiswa, melihat gambaran mengerikan akibat perilaku merokok dapat mempengaruhi motivasi mereka untuk berhenti merokok. Seperti diketahui, bahaya merokok tidak hanya mengancam perokok itu sendiri, tapi juga membahayakan orang di sekitar mereka. Sayangnya dalam penelitian ini, persepsi dampak negatif merokok tidak berpengaruh signifikan terhadap motivasi berhenti merokok. Meskipun dalam penelitian ini tidak terbukti berpengaruh signifikan, penelitian lanjutan terhadap variabel ini penting dilakukan. Misalnya dari sisi orang disekitar yang terkena 
dampak dari asap rokok orang lain. Tekanan sosial dari perokok pasif secara bersama-sama akan membantu para perokok menyadari dampak negatif yang dia timbulkan bagi orang lain meskipun sebenarnya bagi dirinya sendiri juga akan mendapat dampak negatif. Selain itu, penelitian lebih lanjut diharapkan dapat menguji variabel lain yang memiliki pengaruh lebih signifikan untuk diandalkan dalam membuat strategi kampanye berhenti merokok.

\section{DAFTAR PUSTAKA}

Chen, X., Stanton, B., Fang, X., Li, X., Lin, D., Zhang, J., Liu, H., \& Yang, H. 2006. Perceived Smoking Norms, Socioenvironmental Factors, Personal Attitudes and Adolescent Smoking In China: A Mediation Analysis with Longitudinal Data, Journal of Adolescent Health, 38, Pp. 359-368.

Davis, K.C., Nonnemaker, J.M., \& Farrelly, M.C. 2007. Association between National Smoking Prevention Campaigns and Perceived Smoking Prevalence Among Youth in the United States, Journal of Adolescent Health, 41, Pp. 430-436.

Garey, L., Farris, S.G., Schmidt, N.B., \& Zvolensky, M.J. 2015. The Role of Smoking-Specific Experiential Avoidance in the Relation Between Perceived Stress and Tobacco Dependence, Perceived Barriers to Cessation, and Problems during Quit Attempts Among Treatment-Seeking
Smokers, Journal of

Contextual Behavioral Science, http://dx.doi.org/10.1016/j.jcbs. 2015.11.001.

Garey, L., Kauffman, B.Y., Neighbors, C., Schmidt, N.B., \& Zvolensky, M.J. 2016. Treatment Attrition: Associations with Negative Affect Smoking Motives and Barriers to Quitting among Treatment-Seeking Smokers, Addictive Behaviors, 63, Pp.165-171.

Glock, S., Unz, D., \& Kovacs, C. 2012. Beyond Fear Appeals: Contradicting Positive Smoking Outcome Expectancies to Influence Smokers' Implicit Attitudes, Perception, and Behavior, Addictive Behaviors, 37, $\mathrm{Pp}$. 548-551.

Gould, G.S., Watt, K., Cadet-James, Y., \& Clough, A.R. 2015. Using the Risk Behaviour Diagnosis Scale to Understand Australian Aboriginal Smoking - A Cross-Sectional Validation Survey In Regional New South Wales, Preventive Medicine Reports, 2, Pp. 4-9.

Greenaway, R., Mogg, K., \& Bradley, B.P. 2012. Attentional Bias for Smoking-Related Information In Pregnant Women: Relationships With Smoking Experience, Smoking Attitudes and Perceived Harm to Foetus, Addictive Behaviors, 37, Pp. 1025-1028.

Hafid, H. 2015. Gambar Peringatan Ini Ternyata Bikin Perokok Gemetaran, $\quad$ https://m. tempo.co/read/news/2015/05/2 0/173667743/gambar- 
peringatan-ini-ternyata-bikinperokok-gemetaran

Halpern-Felsher, B.L., Biehl, M., Kropp, R.Y., \& Rubinstein, M.L. 2004. Perceived Risks and Benefits of Smoking: Differences Among Adolescents with Different Smoking Experiences and Intentions, Preventive Medicine, 39, Pp. 559-567.

Henriksen, L., \& Flora, J.A. 1999. Third-Person Perception and Children Perceived Impact of Pro- and Anti-Smoking Ads, Communication Research, Vol. 26 No.6, 643-665.

Ioakeimidis, N., Vlachopoulos, C., \& Tousoulis, D. Efficacy and Safety of Electronic Cigarettes for Smoking Cessation: A Critical Approach, Hellenic J Cardiol, 57, Pp. 1-6

MacPherson, L., Collado, A., Ninnemann, A., \& Hoffman, E. 2016. Development of a Behavioral Activation-Based Intervention for CigaretteSmoking Young Adults, Cognitive and Behavioral Practice, http://dx.doi.org/10.1016/j.cbpr a.2016.03.004

McKee, S.A., O’Malley, S.S., Salovey, P., Krishnan-Sarina, S., \& Mazure, C.M. 2005. Perceived Risks and Benefits of Smoking Cessation: GenderSpecific Predictors of Motivation and Treatment Outcome, Addictive Behaviors, 30, Pp. 423-435

Maddux , J.E. \& Rogers, R.W. 1983. Protection Motivation and SelfEfficacy: A Revised Theory of Fear Appeals and Attitude

\author{
Change, Journal of \\ Experimental Social \\ Psychology, 19, 469-479.
}

